\title{
Chemical Composition and Antioxidant Activity of Tánara Ótó (Dracocephalum palmatum Stephan), a Medicinal Plant Used by the North-Yakutian Nomads
}

\author{
Daniil N. Olennikov $^{1, *}$, Nadezhda K. Chirikova ${ }^{2}$, Zhanna M. Okhlopkova ${ }^{3}$ \\ and Ismayl S. Zulfugarov $3,4,5$
}

1 Institute of General and Experimental Biology, Siberian Division, Russian Academy of Science, Sakh'yanovoy str., 6, Ulan-Ude 670047, Russia

2 Department of Biochemistry and Biotechnology, North-Eastern Federal University, 58 Belinsky Str., Yakutsk 677-027, Russia; E-Mail: hofnung@mail.ru

3 Department of Biology, North-Eastern Federal University, 58 Belinsky Str., Yakutsk 677-027, Russia; E-Mails: biotechnologyYSU@rambler.ru (Z.M.O.); iszulfugarov@pusan.ac.kr (I.S.Z.)

4 Department of Molecular Biology, Pusan National University, Pusan 609-735, Korea

5 Institute of Botany, Azerbaijan National Academy of Sciences, Baku AZ 1073, Azerbaijan

* Author to whom correspondence should be addressed; E-Mail: olennikovdn@mail.ru; Tel.: +8-9021-600-627; Fax: +8-3012-434-543.

Received: 11 October 2013; in revised form: 6 November 2013 / Accepted: 8 November 2013 / Published: 14 November 2013

\begin{abstract}
Dracocephalum palmatum Stephan (Lamiaceae) is a medicinal plant used by the North-Yakutian nomads. From the crude ethanolic extract of the aerial parts of this plant, 23 compounds (phenylpropanoids, coumarins, flavonoids, and triterpenes) were isolated. Among these, eight compounds (salvianolic acid B, caftaric acid, cichoric acid, umbelliferone, aesculetin, apigenin-7-O- $\beta$-D-glucuronopyranoside, isorhoifolin, and luteolin-4'-O- $\beta$-D-glucopyranoside) were detected for the first time in the genus Dracocephalum. Their structures were elucidated based on chemical and spectral data. The levels of most of the compounds detected in the cultivated sample were close to that of the wild sample, indicating the reproducibility of the biologically active compounds of D. palmatum through cultivation. Investigation into the biological activity of $D$. palmatum under in vitro conditions demonstrated that its extracts have a strong antioxidant effect due to the presence of high concentrations of phenolic compounds.
\end{abstract}


Keywords: Dracocephalum palmatum Stephan; Lamiaceae; North-Yakutian nomads; flavonoids; phenylpropanoids; antioxidant activity

\section{Introduction}

Yakutia (Sakha), a federal subject of Russia spanning 3,083,523 $\mathrm{km}^{2}$, is the largest subnational governing body by area in the World. If the federal subjects of Russia were compared with other countries, it would the eighth largest territory in the World. More than $40 \%$ of the territory is lies within the Arctic Circle. Due to its geographical location Yakutia is characterised by a variety of habitats and natural resources. Despite the uniqueness and diversity of the Yakutian flora, the scale of bioprospecting has been extremely low. As a part of the scientific programme on the investigation of plant diversity, we are now carrying out comprehensive studies of the chemical composition of Yakutian plants.

Palmate dragonhead Dracocephalum palmatum Stephan (D. schelechowii Turcz. ex Ledeb., Ruyschiana palmata (Stephan ex Willd.) House; Subsection Keimodracontes Briq., Section Buguldea Benth., Subgenus Eudracocephalum Briq., Genus Dracocephalum L., Family Lamiaceae), is a perennial rhizomatous plant with numerous stems and ovate-rounded, pinnatifid leaves, and purple flowers on short stalks gathered in false whorls at the end of the stems in an oblong inflorescence (Figure 1). It grows on cliffs and sandy deposits, on gravelly and rocky slopes. It is endemic to the Arctic tundra (Chukotka, Anadyr), East Siberia (Yakutia), and the Russian Far East region [1].

Figure 1. Palmate dragonhead-Dracocephalum palmatum Stephan.

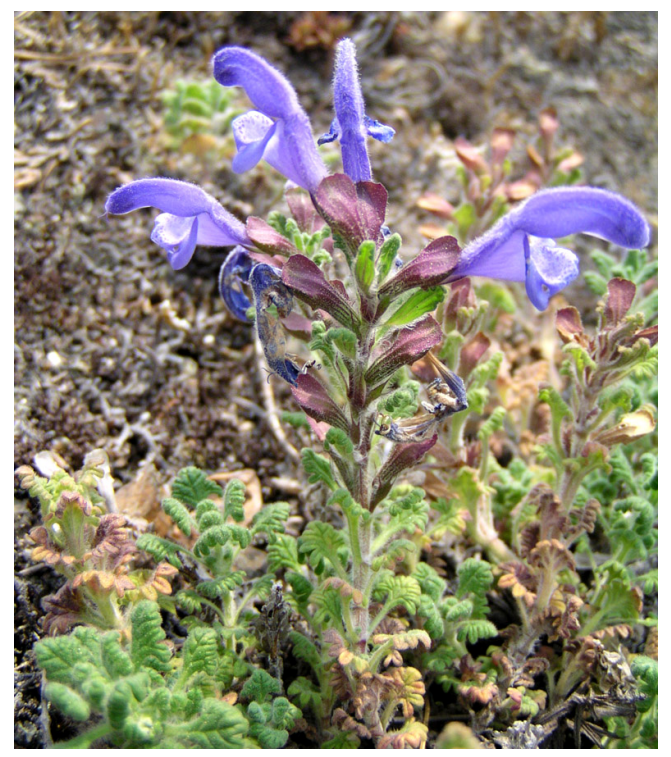

The Nomads of North Yakutia call this plant tánara ótó (may̧apa omo, the herb devoted to the supreme god Tánara). Young shoots and flowers have ethnobotanical uses as diuretic and chloretic remedy, for fumigation, treatment of gastro-intestinal tract disorders and alcoholism [2]. There are no scientific data about the chemical components and biological activity of D. palmatum herb. 
Dracocephalum is a large genus of Lamiaceae family that includes about 60 species as perennial herbs (rarely semishrubs), growing in the territory of the extra-tropical Asia, Europe, and Russia. Ethnopharmacological information about species of this genus allows describing some of them as well-known and valuable sources of drugs. Among them, the most prominent species is D. moldavica L., traditionally used in the ethnomedicine of European countries for the treatment of hypertension and heart disease [3]. The aerial part of D. heterophyllum Benth. was used in Xinjiang (China) for treatment of asthma and gastropathy [4]. The best drug for diseases of the stomach and liver in Tibetian medicine was the herb of D. nutans [5]. In Buryatia (Russia) decoctions from D. ryushiana L. and $D$. argunense Fisch. ex Link. were recommended by ancient doctors (lamas) as choleretic remedies [6]. Despite a long history of human use of Dracocephalum species, scientific data about the chemical composition are known just for 16 species. Approximately a hundred compounds were isolated and identified as derivatives of terpenoids, flavonoids, alkaloids, and others [7]. These facts demonstrated the necessity of expanding scientific information about the species of the genus Dracocephalum. In this study, we present the results of a phytochemical investigation of D. palmatum herb of both wild (collected from Yakutia) and cultivated varieties and the antioxidant activity data of the ethanolic extracts from $D$. palmatum determined by in vitro methods.

\section{Results and Discussion}

\subsection{Chemical Composition of D. palmatum Herb}

The $60 \% \mathrm{EtOH}$ extract of $D$. palmatum herb was partitioned with $\mathrm{CHCl}_{3}, \mathrm{EtOAc}$, and $n-\mathrm{BuOH}$ to yield three fractions, which were separated by column chromatography (gel permeation, normal phase $\left(\mathrm{NP}-\mathrm{SiO}_{2}\right)$ and reversed phase silica gel $\left(\mathrm{RP}-\mathrm{SiO}_{2}\right), \mathrm{XAD}$, polyamide chromatography), preparative (prep.) high performance liquid chromatography (HPLC) and prep. thin layer chromatography (TLC)). Twenty three biologically active compounds, including six phenylpropanoids (caffeic acid (1), 3-O-caffeoylquinic acid (2), rosmarinic acid (3), salvianolic acid B (4), caftaric acid (5), cichoric acid (6)), two coumarins (umbelliferone (7), aesculetin (8)), thirteen flavonoids (apigenin (9), cosmosiin (10), apigenin-7-O- $\beta$-D-glucuronopyranoside (11), isorhoifolin (12), luteolin (13), cynaroside (14), luteolin-7- $O$ $\beta$-D-glucuronopyranoside (15), luteolin-4'-O- $\beta$-D-glucopyranoside (16), scolymoside (17), naringenin (18), naringenin-7-O- $\beta$-D-glucopyranoside (19), eriodictyol (20), eriodictyol-7- $O$ - $\beta$-D-glucopyranoside (21)) and two triterpenes (ursolic acid (22), oleanolic acid (23)), were identified by comparing their optical rotations, UV, MS and NMR data with that reported in the literature (Figure 2).

It should be noted that compounds 1-3, 9, 10, 13, 14, 22 and 23 are widely distributed in the Lamiaceae family and genus Dracocephalum [7]; compound 15 was previously isolated from D. integrifolium Bunge [8], 17 from D. peregrinum L. [9], 18-21 from D. peregrinum, D. rupestre Hance, and D. tanguticum Maxim. [7]. Eight components (compounds 4-8, 11, 12, 16) were detected for the first time in the genus Dracocephalum.

Despite insufficient chemical information of the phenolic compounds of Dracocephalum genus, available data suggest that flavonoid compounds, particularly derivatives of apigenin and luteolin, i.e., flavones with 5,7,4' and 5,7,3',4' types of substitution are specific to this genus. These substances were found in the majority of Dracocephalum species studied, thus reflecting their important 
chemosystematic character. The systematic function of rosmarinic acid, a specific marker for Lamiaceae family, is not clear because its presence has not been detected in all Dracocephalum species. However, it should be noted that caffeic acid and its derivatives are an essential part of the Dracocephalum genus extracts.

Figure 2. Chemical structures of compounds 1-23 isolated from D. palmatum herb.<smiles>O=C(O)/C=C/c1ccc(O)c(O)c1</smiles>

1<smiles>O=C(/C=C/c1ccc(O)c(O)c1)OC(C(=O)O)C(O)C(=O)O</smiles>
5<smiles>[R6]Oc1cc(O)c2c(=O)cc(-c3ccc(O[R9])c([R2])c3)oc2c1</smiles>

$9 \mathrm{R}_{1}=\mathrm{R}_{2}=\mathrm{R}_{3}=\mathrm{H}$

$10 \mathrm{R}_{1}=\beta-\mathrm{D}-\mathrm{Glc} p, \mathrm{R}_{2}=\mathrm{R}_{3}=\mathrm{H}$

$11 \mathrm{R}_{1}=\beta$-D-GlcA $p, \mathrm{R}_{2}=\mathrm{R}_{3}=\mathrm{H}$

$12 \mathrm{R}_{1}=\left(6^{\prime \prime}-\alpha-\mathrm{L}-\mathrm{Rha} p\right)-\beta-\mathrm{D}-\mathrm{Glc} p, \mathrm{R}_{2}=\mathrm{R}_{3}=\mathrm{H}$

$13 \mathrm{R}_{1}=\mathrm{R}_{3}=\mathrm{H}, \mathrm{R}_{2}=\mathrm{OH}$

$14 \mathrm{R}_{1}=\beta$-D-Glc $p, \mathrm{R}_{2}=\mathrm{OH}, \mathrm{R}_{3}=\mathrm{H}$

$15 \mathrm{R}_{1}=\beta$-D-GlcA $p, \mathrm{R}_{2}=\mathrm{OH}, \mathrm{R}_{3}=\mathrm{H}$

$16 \mathrm{R}_{1}=\mathrm{H}, \mathrm{R}_{2}=\mathrm{OH}, \mathrm{R}_{3}=\beta-\mathrm{D}-\mathrm{Glc} p$

$17 \mathrm{R}_{1}=\left(6^{\prime \prime}-\alpha-\mathrm{L}-\mathrm{Rha} p\right)-\beta-\mathrm{D}-\mathrm{Glc} p, \mathrm{R}_{2}=\mathrm{OH}, \mathrm{R}_{3}=\mathrm{H}$

$\beta$-D-Glcp- $\beta$-D-glucopyranose; $\beta$-D-GlcAp $-\beta$-D-glucuronopyranose; $\alpha$-L-Rhap $-\alpha$-L-rhamnopyranose.

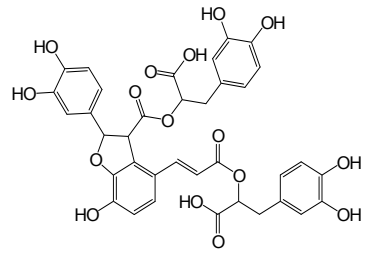

4<smiles>O=C(/C=C/c1ccc(O)c(O)c1)OC(C(=O)O)C(OC(=O)/C=C/c1ccc(O)c(O)c1)C(=O)O</smiles><smiles>[R]c1cc2ccc(=O)oc2cc1O</smiles>

$7 \mathrm{R}=\mathrm{H}$

6<smiles>[R20]c1cc(O)c2c(c1)OC(c1ccc(O)c([R2])c1)CC2=O</smiles>

$8 \mathrm{R}=\mathrm{OH}$<smiles>C=C1C(O)CCC2(C)C1CCC1C3CCC4(C(=O)O)CCC5CC5CC4C3(C)CCC12C</smiles>

23

$18 \mathrm{R}_{1}=\mathrm{R}_{2}=\mathrm{H}$

$19 \mathrm{R}_{1}=\beta-\mathrm{D}-\mathrm{Glc} p, \mathrm{R}_{2}=\mathrm{H}$

$20 \mathrm{R}_{1}=\mathrm{H}, \mathrm{R}_{2}=\mathrm{OH}$

$21 \mathrm{R}_{1}=\beta-\mathrm{D}-\mathrm{Glc} p, \mathrm{R}_{2}=\mathrm{OH}$

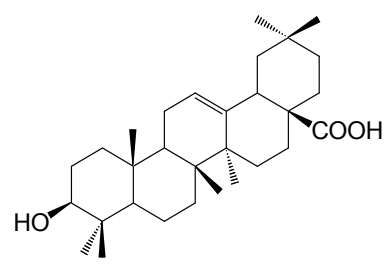

24

\subsection{HPLC-UV Analysis of the Main Phenolic Compounds in D. palmatum}

A quantitative analysis of the phenolic compounds found in D. palmatum was performed using microcolumn HPLC with ultraviolet detection (HPLC-UV), which allowed separation of 15 dominant components (Figure 3). The predominant phenolic compounds from the wild sample of D. palmatum are flavonoids $(20.987 \mathrm{mg} / \mathrm{g})$ and the main group of the flavonoids is flavones $(20.844 \mathrm{mg} / \mathrm{g})$, with cynaroside $(12.075 \mathrm{mg} / \mathrm{g})$ and cosmosiin $(5.683 \mathrm{mg} / \mathrm{g})$ as dominating compounds (Table 1). Luteolin and its derivatives accounted for about $70 \%$ of the total flavonoids and apigenin and its derivatives accounted for less than $30 \%$. The amount of flavanones did not exceed $1 \%$ of the total flavonoids. The content of glycosides was 11 times more than that of aglycones. Among glycosides, monoglycosides 
were dominant $(19.420 \mathrm{mg} / \mathrm{g}$ ) and the biosides (rutinosides) represented about $3 \%$ of the total amount of flavonoids. The content of phenylpropanoids in D. palmatum did not exceed $15 \%$ of the identified phenolic compounds. The dominant components of this group of metabolites were rosmarinic acid $(1.614 \mathrm{mg} / \mathrm{g})$ and salvianolic acid B (1.456 mg/g).

Figure 3. HPLC chromatograms of ethanolic extracts from wild and cultivated samples of D. palmatum at $270 \mathrm{~nm}$. Samples: I—wild plant; II—cultivated plant.

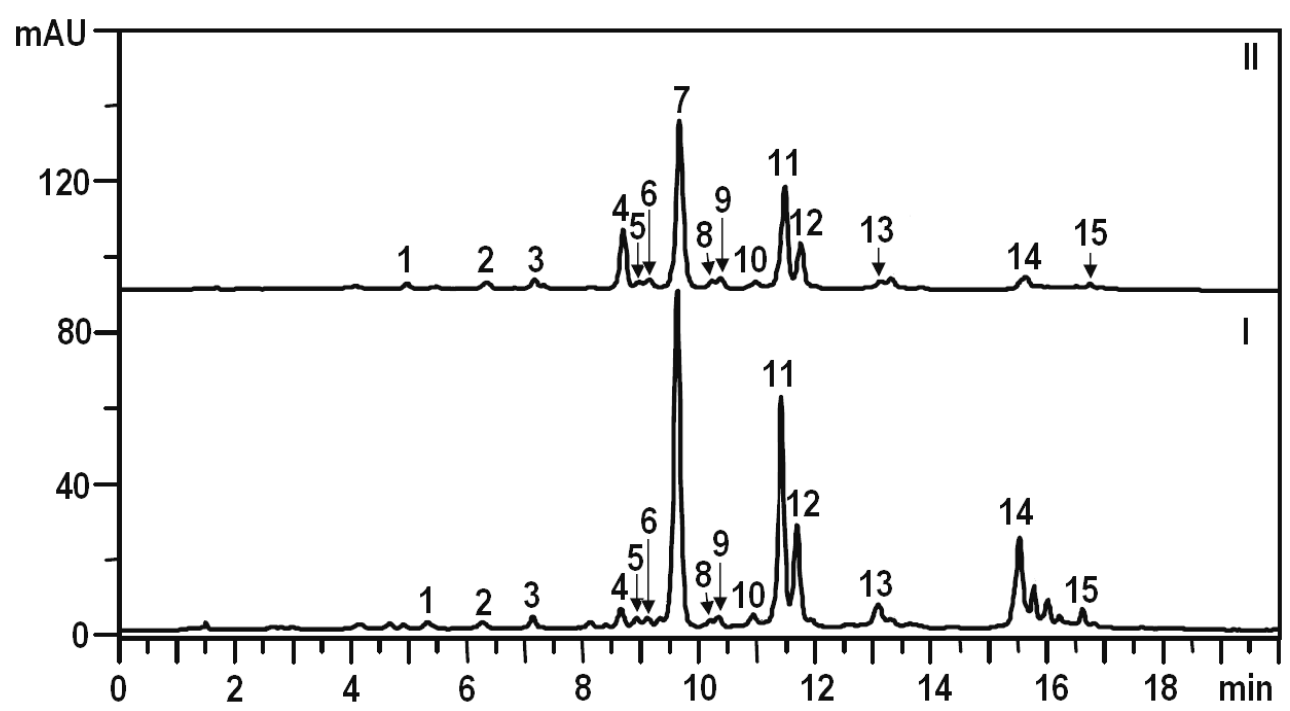

1. 3-O-Caffeoylquinic acid; 2. caffeic acid; 3. cichoric acid; 4. scolymoside; 5. eriodictyol-7-Oglucoside; 6. luteolin-7-O-glucuronide; 7. cynaroside; 8. luteolin-4'-O-glucoside; 9. isorhoifolin; 10. naringenin-7-O-glucoside; 11. cosmosiin; 12. rosmarinic acid; 13. salvianolic acid B; 14. luteolin; 15. apigenin.

The comparative analysis of the phenolic compounds in wild and cultivated samples of D. palmatum showed that the total content of identified compounds in the cultivated sample was $28 \%$ lower (17.571 mg/g vs. $24.503 \mathrm{mg} / \mathrm{g}$ in wild sample) (Table 2).

It should be noted that the set of compounds detected in the cultivated sample was close to those of the wild sample, except for a significantly higher content of biosides in the cultivated samples $(2.735 \mathrm{mg} / \mathrm{g})$. This indicates the reproducibility of $D$. palmatum composition under artificial culture conditions.

Chromatographic study of the aerial parts of D. palmatum showed an uneven distribution of the phenolic compounds in the plant. The maximum content of identified compounds was observed in the leaves $(37.825 \mathrm{mg} / \mathrm{g})$, minimum in the flowers $(11.251 \mathrm{mg} / \mathrm{g})$ and stems contained an intermediate level $(20.959 \mathrm{mg} / \mathrm{g})$ (Table 1).

The flavonoids were concentrated in the leaves $(35.482 \mathrm{mg} / \mathrm{g})$ and phenylpropanoids accumulated in the stems of plant $(3.982 \mathrm{mg} / \mathrm{g})$. The leaves showed a high content of all flavonoidal groups except aglycone and flavonol-biosides, which were concentrated in the flowers $(2.843 \mathrm{mg} / \mathrm{g})$ and stems $(5.565 \mathrm{mg} / \mathrm{g})$, respectively. The dominating flavonoids in flowers were cynaroside $(5.062 \mathrm{mg} / \mathrm{g})$, luteolin $(1.998 \mathrm{mg} / \mathrm{g})$ and cosmosiin $(1.410 \mathrm{mg} / \mathrm{g})$; in leaves - cynaroside $(25.172 \mathrm{mg} / \mathrm{g})$, cosmosiin $(7.874 \mathrm{mg} / \mathrm{g})$ and scolymoside $(1.240 \mathrm{mg} / \mathrm{g})$; in stems - cynaroside $(6.727 \mathrm{mg} / \mathrm{g})$, scolymoside $(4.188 \mathrm{mg} / \mathrm{g})$ and cosmosiin $(1.640 \mathrm{mg} / \mathrm{g})$. A high content of such rare flavonoids such as isorhoifolin, luteolin-7-O- 
glucuronide, and luteolin-4'-O-glucoside were detected in the stems of plants $(1.377,0.580$, and $0.376 \mathrm{mg} / \mathrm{g}$, respectively). The organ with maximal phenylpropanoid content was the stem $(3.982 \mathrm{mg} / \mathrm{g})$ characterised by the highest concentration of rosmarinic acid $(2.791 \mathrm{mg} / \mathrm{g}$, that is 4.1 times more than in the leaves and 9 times higher than in the flowers. Unlike rosmarinic acid, salvianolic acid B accumulates in leaves $(1.662 \mathrm{mg} / \mathrm{g})$. The detected concentrations of 3-O-caffeoylquinic acid, caffeic acid and cichoric acid were found only in the stems. The distribution of phenolics in the organs of the cultivated sample of $D$. palmatum was similar to that of the wild sample (Table 2). However, for a number of compounds, higher levels were found in cultivated samples. For example, stems of the cultivated sample were enriched with caffeic acid, scolymoside, and eriodictyol-7-O-glucoside. In the leaves of wild sample, trace amounts of cichoric acid were observed, whereas in the cultivated plant, the concentration of this compound was up to $0.356 \mathrm{mg} / \mathrm{g}$. The above results demonstrate that D. palmatum is a plant with a high content of flavonoids.

Table 1. Content of phenolic compounds in wild samples of D. palmatum $(\mathrm{mg} / \mathrm{g}$ of dry plant weight).

\begin{tabular}{|c|c|c|c|c|}
\hline \multirow{2}{*}{ Compound } & \multicolumn{4}{|c|}{ Average amount \pm SD } \\
\hline & Herb & Flowers & Leaves & Stems \\
\hline 3-O-Caffeoylquinic acid & $0.052 \pm 0.001^{\mathrm{a}}$ & tr. & tr. & $0.063 \pm 0.001^{\mathrm{a}}$ \\
\hline Caffeic acid & $0.157 \pm 0.002^{b}$ & $\operatorname{tr}$. & n.d. & $0.512 \pm 0.005^{\mathrm{e}}$ \\
\hline Cichoric acid & $0.237 \pm 0.003^{c}$ & n.d. & tr. & $0.289 \pm 0.003^{\mathrm{cd}}$ \\
\hline Rosmarinic acid & $1.614 \pm 0.022^{\mathrm{i}}$ & $0.311 \pm 0.003^{\mathrm{cd}}$ & $0.681 \pm 0.004^{\mathrm{f}}$ & $2.791 \pm 0.021^{\mathrm{j}}$ \\
\hline Salvianolic acid B & $1.456 \pm 0.018^{\mathrm{hi}}$ & $0.431 \pm 0.004^{\mathrm{e}}$ & $1.662 \pm 0.018^{i}$ & $0.327 \pm 0.003^{d}$ \\
\hline Apigenin & $0.315 \pm 0.004^{\mathrm{cd}}$ & $0.845 \pm 0.010^{\mathrm{g}}$ & $0.370 \pm 0.003^{\mathrm{d}}$ & $0.497 \pm 0.006^{\mathrm{e}}$ \\
\hline Cosmosiin & $5.683 \pm 0.085^{\mathrm{k}}$ & $1.410 \pm 0.014^{\mathrm{hi}}$ & $7.874 \pm 0.094^{1}$ & $1.640 \pm 0.018^{\mathrm{i}}$ \\
\hline Isorhoifolin & $0.240 \pm 0.003^{c}$ & $0.295 \pm 0.003^{c}$ & $0.145 \pm 0.002^{b}$ & $1.377 \pm 0.016^{\mathrm{h}}$ \\
\hline Luteolin & $1.484 \pm 0.018^{\mathrm{hi}}$ & $1.998 \pm 0.026^{\mathrm{i}}$ & $0.252 \pm 0.003^{c}$ & $1.246 \pm 0.014^{\mathrm{h}}$ \\
\hline Cynaroside & $12.075 \pm 0.156^{\mathrm{m}}$ & $5.062 \pm 0.065^{\mathrm{k}}$ & $25.172 \pm 0.276^{\mathrm{n}}$ & $6.727 \pm 0.074^{\mathrm{k}}$ \\
\hline Luteolin-7-O-glucuronide & $0.298 \pm 0.004^{\mathrm{c}}$ & $0.212 \pm 0.002^{\mathrm{c}}$ & tr. & $0.580 \pm 0.006^{\mathrm{e}}$ \\
\hline Luteolin-4'-O-glucoside & $0.254 \pm 0.003^{c}$ & tr. & tr. & $0.376 \pm 0.001^{\mathrm{d}}$ \\
\hline Scolymoside & $0.495 \pm 0.007^{\mathrm{e}}$ & $0.445 \pm 0.005^{\mathrm{e}}$ & $1.240 \pm 0.011^{\mathrm{h}}$ & $4.188 \pm 0.046^{\mathrm{k}}$ \\
\hline Naringenin-7-O-glucoside & $0.143 \pm 0.003^{b}$ & $0.163 \pm 0.002^{b}$ & $0.272 \pm 0.002^{\mathrm{c}}$ & $0.251 \pm 0.003^{\mathrm{c}}$ \\
\hline Eriodictyol-7-O-glucoside & tr. & $0.079 \pm 0.001^{\mathrm{a}}$ & $0.157 \pm 0.002^{\mathrm{b}}$ & $0.095 \pm 0.001^{\mathrm{a}}$ \\
\hline Total identified compounds & 24.503 & 11.251 & 37.825 & 20.959 \\
\hline Phenylpropanoids & 3.516 & 0.742 & 2.343 & 3.982 \\
\hline Flavonoids, including & 20.987 & 10.509 & 35.482 & 16.977 \\
\hline flavanones & 0.143 & 0.242 & 0.429 & 0.346 \\
\hline flavones & 20.844 & 10.267 & 35.053 & 16.631 \\
\hline apigenin derivatives & 6.238 & 2.550 & 8.389 & 3.514 \\
\hline luteolin derivatives & 14.606 & 7.717 & 26.664 & 13.117 \\
\hline alycones & 1.799 & 2.843 & 0.622 & 1.743 \\
\hline monoglycosides & 19.420 & 6.926 & 33.475 & 9.669 \\
\hline biosides & 0.735 & 0.740 & 1.385 & 5.565 \\
\hline
\end{tabular}

All values correspond to mean values \pm standard deviation of three replicates. Values with different letters $(\mathrm{a}-\mathrm{n})$ indicate statistically significant differences among groups at $p<0.05$ by one-way ANOVA. tr. - traces ( $<$ limit of quantification); n.d. - not detected ( $<$ limit of detection). 
Table 2. Content of phenolic compounds in cultivated samples of D. palmatum $(\mathrm{mg} / \mathrm{g}$ of dry plant weight).

\begin{tabular}{|c|c|c|c|c|}
\hline \multirow{2}{*}{ Compound } & \multicolumn{4}{|c|}{ Average amount \pm SD } \\
\hline & Herb & Flowers & Leaves & Stems \\
\hline 3-O-Caffeoylquinic acid & $0.043 \pm 0.001^{\mathrm{a}}$ & tr. & tr. & tr. \\
\hline Caffeic acid & $0.246 \pm 0.003^{c}$ & $\operatorname{tr}$. & $\operatorname{tr}$. & $0.755 \pm 0.009^{f}$ \\
\hline Cichoric acid & $0.122 \pm 0.001^{\mathrm{b}}$ & $\operatorname{tr}$. & $0.356 \pm 0.003^{d}$ & $0.203 \pm 0.002^{\mathrm{c}}$ \\
\hline Rosmarinic acid & $0.943 \pm 0.012^{\mathrm{g}}$ & $0.139 \pm 0.001^{b}$ & $0.264 \pm 0.003^{c}$ & $1.943 \pm 0.021^{\mathrm{h}}$ \\
\hline Salvianolic acid B & $0.651 \pm 0.008^{\text {ef }}$ & $\operatorname{tr}$. & $1.307 \pm 0.010^{\mathrm{gh}}$ & $0.171 \pm 0.002^{b c}$ \\
\hline Apigenin & $0.157 \pm 0.002^{b}$ & $0.182 \pm 0.002^{b c}$ & $\operatorname{tr}$. & $0.312 \pm 0.003^{\mathrm{d}}$ \\
\hline Cosmosiin & $3.253 \pm 0.046^{\mathrm{i}}$ & $0.197 \pm 0.002^{b c}$ & $6.073 \pm 0.067^{\mathrm{j}}$ & $1.002 \pm 0.012^{\mathrm{g}}$ \\
\hline Isorhoifolin & $0.273 \pm 0.004^{\mathrm{c}}$ & tr. & $0.101 \pm 0.001^{\mathrm{b}}$ & $0.340 \pm 0.004^{\mathrm{d}}$ \\
\hline Luteolin & $0.298 \pm 0.004^{\mathrm{c}}$ & $0.512 \pm 0.004^{\mathrm{e}}$ & $0.396 \pm 0.003^{d}$ & $0.203 \pm 0.002^{\mathrm{c}}$ \\
\hline Cynaroside & $8.263 \pm 0.132^{\mathrm{k}}$ & $0.545 \pm 0.007^{\mathrm{e}}$ & $15.682 \pm 0.173^{1}$ & $2.972 \pm 0.032^{h i}$ \\
\hline Luteolin-7-O-glucuronide & $0.412 \pm 0.005^{\mathrm{de}}$ & tr. & $0.605 \pm 0.007^{\mathrm{ef}}$ & $0.143 \pm 0.001^{b}$ \\
\hline Luteolin-4'-O-glucoside & $0.337 \pm 0.004^{\mathrm{d}}$ & $\operatorname{tr}$. & $0.568 \pm 0.006^{\mathrm{e}}$ & $0.123 \pm 0.001^{\mathrm{b}}$ \\
\hline Scolymoside & $2.462 \pm 0.032^{\mathrm{h}}$ & $0.083 \pm 0.001^{a b}$ & $0.749 \pm 0.009^{\mathrm{f}}$ & $5.266 \pm 0.058^{\mathrm{j}}$ \\
\hline Naringenin-7-O-glucoside & $0.111 \pm 0.002^{b}$ & $0.114 \pm 0.001^{b}$ & $1.204 \pm 0.014^{\mathrm{gh}}$ & $0.083 \pm 0.001^{\mathrm{ab}}$ \\
\hline Eriodictyol-7-O-glucoside & tr. & tr. & tr. & $0.212 \pm 0.002^{\mathrm{c}}$ \\
\hline Total identified compounds & 17.571 & 1.772 & 27.305 & 13.728 \\
\hline Phenylpropanoids & 2.005 & 0.139 & 1.927 & 3.072 \\
\hline Flavonoids, including & 15.566 & 1.633 & 25.378 & 10.656 \\
\hline flavanones & 0.111 & 0.114 & 1.204 & 0.295 \\
\hline flavones & 15.455 & 1.519 & 24.174 & 10.361 \\
\hline apigenin derivatives & 3.683 & 0.379 & 6.174 & 1.654 \\
\hline luteolin derivatives & 11.772 & 1.114 & 18.000 & 8.707 \\
\hline alycones & 0.455 & 0.694 & 0.396 & 0.515 \\
\hline monoglycosides & 13.158 & 0.856 & 24.132 & 4.535 \\
\hline biosides & 2.735 & 0.083 & 0.850 & 5.606 \\
\hline
\end{tabular}

All values correspond to mean values \pm standard deviation of three replicates. Values with different letters (a-l) indicate statistically significant differences among groups at $p<0.05$ by one-way ANOVA. tr. - traces ( $<$ limit of quantification); n.d. — not detected (<limit of detection).

\subsection{Antioxidant Activity of D. palmatum}

Experimental investigations of the ethanolic extracts from wild (WSE) and cultivated samples (CSE) of D. palmatum herb were conducted using the traditional assays: total antioxidant capacity; 2,2-diphenyl-1picrylhydrazyl radical ( $\mathrm{DPPH}^{*}$ ) scavenging activity; 2,2'-azino-bis(3-ethylbenzthiazoline-6-sulphonic acid) radical $\left(\mathrm{ABTS}^{\circ+}\right.$ ) scavenging activity, bromine radical $\left(\mathrm{Br}^{\circ}\right)$ scavenging activity; carotene bleaching assay; nitric oxide (NO) inactivating activity; hydrogen peroxide $\left(\mathrm{H}_{2} \mathrm{O}_{2}\right)$ inactivating activity; ferrous (II) ions $\left(\mathrm{Fe}^{2+}\right)$ chelating activity; ferric reducing antioxidant power; erythrocyte membrane stabilising activity (Table 3). All experiments include the determination and comparative estimation of the same antioxidant factors for cynaroside, the predominant component of D. palmatum with known antioxidant activity [10]. 
Table 3. Antioxidant activity of ethanolic extracts from wild (WSE) and cultivated samples (CSE) of D. palmatum and cynaroside ${ }^{\mathrm{a}}$.

\begin{tabular}{|c|c|c|c|}
\hline Method $^{\text {b }}$ & WSE & CSE & Cynaroside \\
\hline TAC, mg caffeic acid $\mathrm{g}^{-1}$ & $312.44 \pm 6.87^{\mathrm{i}}$ & $284.63 \pm 5.69^{i}$ & $623.16 \pm 13.08^{\mathrm{i}}$ \\
\hline $\mathrm{DPPH}^{\bullet} \mathrm{SA}, \mathrm{IC}_{50}, \mu \mathrm{g} / \mathrm{mL}$ & $12.73 \pm 0.31^{\mathrm{iii}}$ & $18.62 \pm 0.45^{\mathrm{iii}}$ & $17.63 \pm 0.38^{\mathrm{iii}}$ \\
\hline $\mathrm{ABTS}^{\bullet+} \mathrm{SA}, \mathrm{IC}_{50}, \mu \mathrm{g} / \mathrm{mL}$ & $6.35 \pm 0.16^{\mathrm{iv}}$ & $10.78 \pm 0.28^{\mathrm{iv}}$ & $9.38 \pm 0.23^{\text {iv }}$ \\
\hline $\mathrm{Br}^{*} \mathrm{SA}, \mathrm{mg}$ cynaroside $\mathrm{g}^{-1}$ & $389.74 \pm 8.18^{v}$ & $247.86 \pm 4.95^{\mathrm{v}}$ & 1000 \\
\hline $\mathrm{O}_{2}{ }^{--}-\mathrm{SA}, \mathrm{IC}_{50}, \mu \mathrm{g} / \mathrm{mL}$ & $19.37 \pm 0.50^{\mathrm{vi}}$ & $28.63 \pm 0.77^{\mathrm{vi}}$ & $14.84 \pm 0.41$ vi \\
\hline $\mathrm{CBA}, \mathrm{IC}_{50}, \mu \mathrm{g} / \mathrm{mL}$ & $1.64 \pm 0.05^{\mathrm{vii}}$ & $3.38 \pm 0.11^{\mathrm{vii}}$ & $10.28 \pm 0.35^{\text {viii }}$ \\
\hline NO-IA, $\mathrm{IC}_{50}, \mu \mathrm{g} / \mathrm{mL}$ & $29.33 \pm 1.20^{\mathrm{ix}}$ & $41.77 \pm 1.67^{\mathrm{ix}}$ & $>100$ \\
\hline $\mathrm{H}_{2} \mathrm{O}_{2}-\mathrm{IA}, \mathrm{mM} \mathrm{g}^{-1}$ & $2.03 \pm 0.09^{\mathrm{x}}$ & $1.18 \pm 0.05^{\mathrm{x}}$ & $0.52 \pm 0.03^{\mathrm{x}}$ \\
\hline $\mathrm{Fe}-\mathrm{CA}, \mathrm{IC}_{50}, \mu \mathrm{g} / \mathrm{mL}$ & $30.91 \pm 1.08^{\mathrm{xi}}$ & $48.11 \pm 1.62^{\mathrm{xi}}$ & $>100$ \\
\hline FRAP, $\mathrm{mM} \mathrm{Fe}^{2+} \mathrm{g}^{-1}$ & $22.25 \pm 0.85^{\mathrm{xii}}$ & $12.22 \pm 0.48^{\text {xiii }}$ & $9.53 \pm 0.47^{\text {xii }}$ \\
\hline EM-SA, $\mathrm{IC}_{50}, \mu \mathrm{g} / \mathrm{mL}$ & $14.07 \pm 0.70^{\text {xiv }}$ & $51.60 \pm 2.68^{\mathrm{xv}}$ & $25.67 \pm 1.23^{\mathrm{xiv}}$ \\
\hline
\end{tabular}

${ }^{a}$ Average of three analyses $( \pm \mathrm{SD}){ }^{\mathrm{b}}{ }^{\mathrm{TAC}}$-total antioxidant capacity; $\mathrm{DPPH}^{\cdot} \mathrm{SA}-\mathrm{DPPH}^{\cdot}$ radical scavenging activity; $\mathrm{ABTS}^{++} \mathrm{SA}-\mathrm{ABTS}^{*+}$ radical scavenging activity; $\mathrm{Br}{ }^{*} \mathrm{SA}-\mathrm{Br}^{*}$ radical scavenging activity; $\mathrm{O}_{2}{ }^{-} \mathrm{SA}$ - superoxide anion radical scavenging activity; $\mathrm{CBA}$-carotene bleaching assay; NO-IA $-\mathrm{NO}$ inactivating activity; $\mathrm{H}_{2} \mathrm{O}_{2}-\mathrm{IA}-\mathrm{H}_{2} \mathrm{O}_{2}$ inactivating activity; $\mathrm{Fe}-\mathrm{CA}-\mathrm{Fe}^{2+}$ chelating activity; FRAP - ferric reducing antioxidant power; EM-SA — erythrocyte membrane stabilising activity. All values correspond to mean values \pm standard deviation of three replicates. Values with different letters (i-xiv) indicate statistically significant differences among groups at $p<0.05$ by one-way ANOVA.

The values of total antioxidant capacity of WSE and CSE were 312.44 and $284.63 \mathrm{mg}$ caffeic acid per gram of extract, respectively. These values indicate a high antioxidant potential of the studied extracts. The radical scavenging activity of WSE and CSE against radicals of different nature (organic, inorganic, neutral, and charged) was much expressed, and in some cases was higher than the same parameter of cynaroside (DPPH ${ }^{*}$ and $\mathrm{ABTS}^{*+}$ scavenging activities). This data classifies D. palmatum extracts as a radical scavenger. The examination of the influence of WSE and CSE on the oxidative destruction of $\beta$-carotene in the oleic acid-DMSO- $\mathrm{H}_{2} \mathrm{O}_{2}$ system demonstrated a high value of antioxidant activity, with $\mathrm{IC}_{50}=1.64$ and $3.38 \mu \mathrm{g} / \mathrm{mL}$, respectively. The feature of this system is the ability to investigate the influence of sample on the presence of a complex of damaging factors, including $\mathrm{H}_{2} \mathrm{O}_{2}, \mathrm{O}_{2}{ }^{--}, \mathrm{OH}^{-}$, and alkyl-radicals that form in this in vitro system. The efficiency of cynaroside in this assay was slightly lower $(10.28 \mu \mathrm{g} / \mathrm{mL})$. The activity of WSE in the $\mathrm{NO}$ and $\mathrm{H}_{2} \mathrm{O}_{2}$ inactivating assays and both the extracts in $\mathrm{Fe}^{2+}$ chelating activity and FRAP assays were characterised as very high because the activity of cynaroside was quite low. The final stage of the biological study was to investigate the ability of the extracts to protect living cells (RBCs) from oxidative damage caused by the influence of Fenton's reagent. The presence of Fenton's reagent causes a cascade of negative reactions leading to loss of integrity of erythrocyte membranes, which in turn lead to cellular death [11]. The WSE has successfully demonstrated high protective properties $\left(\mathrm{IC}_{50}=14.07 \mu \mathrm{g} / \mathrm{mL}\right)$ exceeding those of the reference substance $\left(\mathrm{IC}_{50}=25.67 \mu \mathrm{g} / \mathrm{mL}\right)$.

The obtained chemical information about D. palmatum herb allows characterizing the isolated phenolic compounds as responsible factors stipulated the antioxidant properties of the total extract. Earlier, the expressed antioxidant activity of the aglycone and glucosides of luteolin and apigenin [12], as well as derivatives of caffeic acid [13], have been shown by various researchers. To confirm the 
leading role of flavonoids and phenylpropanoids found in D. palmatum herb in formation of the antioxidant effect of the total extracts, we applied the original methodical approach. The identification of antioxidants present in the extracts realized after HPLC-separation of the extracts samples pretreated with excess of $\mathrm{DPPH}^{*}$ or $\mathrm{ABTS}^{-+}$radicals (DPPH-HPLC or ABTS-HPLC). The reaction between an antioxidant and a radical results in the oxidation of the antioxidant, that leads to a decrease of the corresponding peak areas in the chromatograms. Comparison of the HPLC chromatograms of untreated and radical-treated samples allows to determine the most active compounds. Previously, some plant species, including Lonicera japonica Thunb. [14], Selaginella sinensis (Desv.) Spring. [15], Artemisia gmelinii Webb. ex Stechm. [16], Pueraria lobata (Wild.) Ohwi [17], Arachis hypogaea L. [18] and Eucommia ulmoides Oliv. [19], were successively investigated by this method.

Chromatograms of ethanolic extract from D. palmatum herb (wild sample) spiking with DPPH and $\mathrm{ABTS}^{\circ+}$ radicals are shown in Figure 4a,b, respectively, which present obviously reduced peak areas for some compounds in comparison with untreated sample. Therefore, seven compounds, caffeic acid (peak 2), scolymoside (peak 4), cynaroside (peak 7), cosmosiin (peak 11), rosmarinic acid (peak 12), salvianolic acid B (peak 13) and luteolin (peak 14), in extract of D. palmatum herb possessed antioxidant activity. It should be noted that the peaks of luteolin, cynaroside, cosmosiin, rosmarinic acid and salvianolic acid B decreased more sharply than the other peaks, so it may be concluded that they are the major active compounds.

Figure 4. HPLC chromatograms of ethanolic extracts from wild samples of D. palmatum at $270 \mathrm{~nm}$ before (I) and after (II) prechromatographic reaction with $\mathrm{DPPH}^{\circ}$ (a) and $\mathrm{ABTS}^{*+}$ radicals $(\mathbf{b})$.

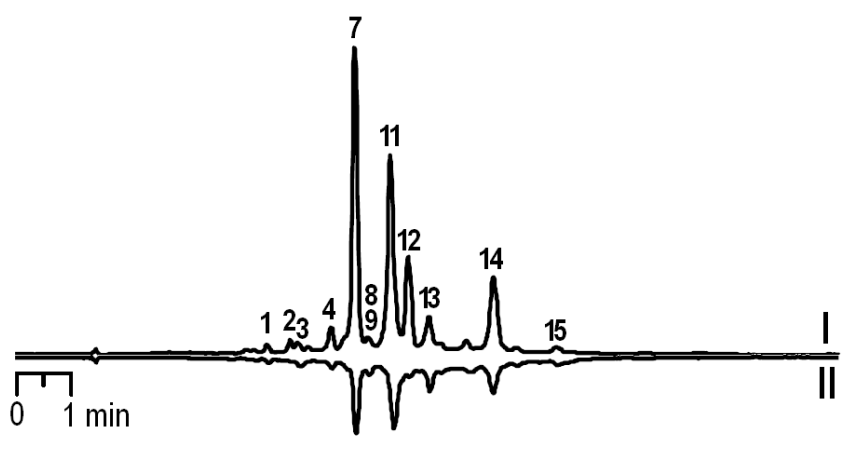

(a)

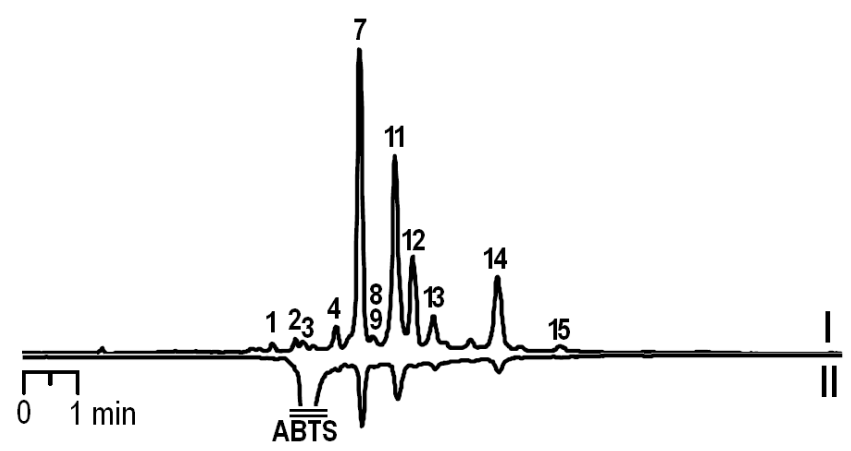

(b)

1. 3-O-Caffeoylquinic acid; 2. caffeic acid; 3. cichoric acid; 4. scolymoside; 7. cynaroside; 8. luteolin-4'-O-glucoside; 9. isorhoifolin; 11. cosmosiin; 12. rosmarinic acid; 13. salvianolic acid B; 14. luteolin; 15. apigenin.

The results of the examination of the antioxidant activity of $D$. palmatum herb indicate that the extracts from this plant strongly scavenge free radicals ( $\mathrm{DPPH}^{\circ}, \mathrm{ABTS}^{{ }^{+}}, \mathrm{Br}^{\circ}, \mathrm{O}_{2}{ }^{-}$) and $\mathrm{NO}$ molecules, inactivate hydrogen peroxide, and chelate $\mathrm{Fe}^{2+}$ ions i.e., exhibit a high antioxidant potential in processes involving hydrogen atom transfer reactions, electron-transfer reaction and other mechanisms. Comparative analysis of the data indicates that in some cases, the antioxidant activity of the extracts was similar to or exceeded the activity of reference antioxidant, cynaroside. 
The unique feature of this plant species is its ability to simultaneously accumulate active compounds such as cynaroside and cosmosiin, which are known to be compounds with high biological activity. In particular, cosmosiin possesses anti-inflammatory [20], insulin-mimetic [21], and cancer prevention activity [22]; cynaroside possesses anti-atherosclerotic [23], anti-inflammatory [24], anti-diabetic [25], and cardioprotective activity [26]. Recently, the effects of cosmosiin against liver injury caused by $\mathrm{CCl}_{4}$ were investigated [27]. It was shown that the application of this phytocomponent not only suppressed the elevation of hepatic stress-indicators, glutamic pyruvic transaminase, glutamic oxaloacetic transaminase, malonic dialdehyde and hydroxydeoxyguanosine, and inhibited the decrease of the reduced glutathione level, but also reduced hepatocyte damage. In addition, in a model of hepatic oxidative injury the normalizing action of cosmosiin on the concentrations of aspartate transaminase, alanine transaminase, alkaline phosphatase, glutamate, total bilirubin, lactate dehydrogenase and total serum protein was demonstrated [28]. The results obtained thus suggest that cosmosiin has protective effects against chemical-induced hepatic damages. Cynaroside is the strongest bioactive component responsible for the detoxification of bromobenzene-induced hepatic lipid peroxidation [29]. A significant protective effect of cynaroside reflects in its reduction of lipid peroxide levels and enhanced activity of epoxide hydrolase, a toxicant agent-removing enzyme, rather than by acting on the epoxide-producing system. The modern data of pharmacological activity of cosmosiin and cynaroside are in good agreement with the ethnoscientifical information concerning the use of D. palmatum as a hepatoprotective agent.

\section{Experimental}

\subsection{General}

Elemental composition was determined using MAT 8200 spectrometer (Thermo Finnigan, Waltham, MA, USA). UV spectra were recorded using a SF-2000 spectrophotometer (OKB Specter, St. Petersburg, Russia). Optical rotations were measured on 341 Series polarimeter (Perkin Elmer, Waltham, MA, USA). MS spectra were registered on a LCQ mass spectrometer (Thermo Finnigan). NMR spectra were recorded on a VXR 500S spectrometer (Varian, Palo Alto, CA, USA). Culometric analysis was performed on an Expert-006 culometric titrator (Econix-Expert, Moscow, Russia). Column chromatography was performed over silica gel 60 (NP-SiO $2 ; 230-400$ mesh, Merck, Whitehouse Station, NJ, USA), Sephadex LH-20 (25-100 $\mu \mathrm{m}$, Pharmacia, Uppsala, Sweden), polyamide Woelm (Waters Associates, Inc., Framingham, MA, USA), octadecyl-functionalised silica gel ( $\mathrm{RP}_{-} \mathrm{SiO}_{2}$; Sigma-Aldrich, St. Louis, MO, USA), and Amberlite XAD7HP (Sigma-Aldrich, St. Louis, MO, USA). Finally, pTLC was performed on Sorbfil-A silica gel TLC plates (layer thickness $2 \mathrm{~mm}$; Imid Ltd., Krasnodar, Russia). All chemicals were analytical-grade.

\subsection{Plant Material}

The wild samples of $D$. palmatum were collected in the vicinity of Tomtor village in Oimyakon

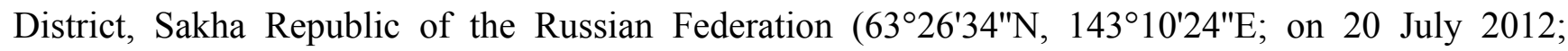
voucher specimen No Lm/h-805/0415). The cultivated plants of D. palmatum were grown from authenticated seeds obtained from Tsitsin's Botanical Garden, Russian Academy of Science (Moscow, 
Russia) by cultivation in the fields of the Botanical Garden of Institute of Biology (IB, Yakutsk, Russia; $\left.62^{\circ} 08^{\prime} 60^{\prime \prime} \mathrm{N}, 129^{\circ} 61^{\prime} 67^{\prime \prime} \mathrm{E}\right)$. The aboveground parts of the plants were collected in the middle of July 2012, then dried and stored at $4{ }^{\circ} \mathrm{C}$ in the IB Plant Repository (voucher specimen No Lm/h-514/0086). For analytical HPLC total probes of the flowers, leaves, stems and herb from 15 specimens of D. palmatum were used.

\subsection{Extraction and Isolation}

The wild samples of D. palmatum $(0.85 \mathrm{~kg})$ were air-dried, ground, and extracted with $60 \% \mathrm{EtOH}$ $(8.5 \mathrm{~L})$ at $80^{\circ} \mathrm{C}$ three times and the extracts were concentrated under reduced pressure to yield $272 \mathrm{~g}$ of crude extract. The crude extract was resuspended in water $(1: 5, \mathrm{v} / \mathrm{v})$ and successively partitioned with hexane, $\mathrm{CHCl}_{3}$, EtOAc, and $n$-BuOH. The organic layers were dried in vacuo to yield 59.5, 25.5, 42.5 and $102.4 \mathrm{~g}$ of hexane $(\mathrm{F} 1), \mathrm{CHCl}_{3}(\mathrm{~F} 2)$, EtOAc (F3) and $n-\mathrm{BuOH}(\mathrm{F} 4)$ fraction residues respectively. The F2 fraction (20 g) was chromatographed over silica column $(3 \times 120 \mathrm{~cm})$, eluting with $\mathrm{CHCl}_{3}-\mathrm{MeOH}$ $(100: 0 \rightarrow 0: 100)$ to obtain 10 fractions (frs. F2/1-F2/10). Fractions F2/3-F2/4 were combined and chromatographed on a silica column $(1.5 \times 70 \mathrm{~cm})$, eluting with hexane-EtAc $(100: 0 \rightarrow 70: 30)$ to obtain 10 fractions (frs. F2/3-4/1 to F2/3-4/10). Frs. F2/3-4/2 to F2/3-4/4 were combined and crystallized from hexane- $\mathrm{CHCl}_{3}$ to give ursolic acid $(22 ; 6.73 \mathrm{~g})$ [30]; frs. F2/3-4/5 to F2/3-4/6 after crystallisation from $\mathrm{CHCl}_{3}$ yielded oleanolic acid (23; $\left.108 \mathrm{mg}\right)$ [31]. Frs. F2/6-F2/8 were combined and chromatographed on a Sephadex LH-20 column $(2 \times 100 \mathrm{~cm})$, eluting with $\mathrm{CHCl}_{3}-\mathrm{MeOH}$ $(100: 0 \rightarrow 0: 100$ ) to obtain 10 fractions (frs. F2/6-8/1 to F2/6-8/10). Frs. F2/6-8/3 to F2/6-8/5 were combined and separated using pTLC (solvent: toluene-EtOAc-HCOOH 6:3:1) to give umbelliferon (7; $24 \mathrm{mg}$ ) and aesculetin $(8 ; 32 \mathrm{mg})$ [31]. Frs. F2/6-8/6 to F2/6-8/7 were combined and crystallized from $\mathrm{MeOH}$ to give apigenin $(\mathbf{9} ; 86 \mathrm{mg})$ [32]. Fr. F3 (41 g) was subjected on a XAD7HP column (600 g), eluting with $\mathrm{H}_{2} \mathrm{O}(10 \mathrm{~L}), 40 \% \mathrm{EtOH}(14 \mathrm{~L})$ and $90 \% \mathrm{EtOH}(8 \mathrm{~L})$. These elutes were brought dried in vacuo to yield 2.6, 29.4 and $8.1 \mathrm{~g}$ of $\mathrm{H}_{2} \mathrm{O}$ (F3-1), 40\% EtOH (F3-2) and 90\% EtOH fraction (F3-3) residue respectively. Fr. F3-2 was chromatographed on polyamide column $(4 \times 120 \mathrm{~cm})$, eluting with $\mathrm{H}_{2} \mathrm{O}-\mathrm{MeOH}(100: 0 \rightarrow 0: 100)$ to obtain 10 fractions (fr. F3-2/1 to fr. F3-2/10). Frs. F3-2/2 and F3-2/3 were separated on Sephadex LH-20 column $(3 \times 110 \mathrm{~cm})$, eluting with $\mathrm{MeOH}-\mathrm{H}_{2} \mathrm{O}$ $(100: 0 \rightarrow 0: 100)$ to obtain caftaric acid $(5 ; 27 \mathrm{mg})$ [33], 3-O-caffeoylquinic acid (2;85 $\mathrm{mg})$ and caffeic acid (1; $64 \mathrm{mg})$ [34], cichoric acid (6; $39 \mathrm{mg})$ [33], respectively. Frs. F3-2/4-F3-2/6 were combined and separated on $\mathrm{RP}-\mathrm{SiO}_{2}$ column $(3 \times 100 \mathrm{~cm})$, eluting with $\mathrm{H}_{2} \mathrm{O}-\mathrm{MeCN}(100: 0 \rightarrow 0: 100)$ to give apigenin-7-O- $\beta$-D-glucuronopyranoside $(11 ; 18 \mathrm{mg})$, cosmosiin $(\mathbf{1 0} ; 242 \mathrm{mg})$, cynaroside $(14 ; 1.84 \mathrm{~g})$, luteolin-7-O- $\beta$-D-glucuronopyranoside $(\mathbf{1 5} ; 37 \mathrm{mg})$, luteolin-4'- $O-\beta$-D-glucopyranoside $(\mathbf{1 6} ; 27 \mathrm{mg})[32$ ]. Frs. F3-2/7-F3-2/9 were combined and separated on $\mathrm{RP}_{-} \mathrm{SiO}_{2}$ column $(3 \times 100 \mathrm{~cm})$, eluting with $\mathrm{H}_{2} \mathrm{O}-\mathrm{MeCN}(100: 0 \rightarrow 0: 100)$ to give naringenin-7-O- $\beta$-D-glucopyranoside $(\mathbf{1 9} ; 31 \mathrm{mg})$ and eriodictyol7-O- $\beta$-D-glucopyranoside (21; $24 \mathrm{mg})$ [32]. Fr. F3-3 was chromatographed on silica column $(2.5 \times 90 \mathrm{~cm})$, eluting with EtAc-MeOH $(100: 0 \rightarrow 70: 30)$ to obtain luteolin $(\mathbf{1 3} ; 104 \mathrm{mg})$, naringenin $(\mathbf{1 8} ; 11 \mathrm{mg})$ and eriodictyol (20; $9 \mathrm{mg})$ [32]. Fr. F4 (80 g) was subjected on a XAD7HP column (900 g), eluting with $\mathrm{H}_{2} \mathrm{O}(25 \mathrm{~L}), 40 \% \mathrm{EtOH}(30 \mathrm{~L})$ and $90 \% \mathrm{EtOH}(6 \mathrm{~L})$. The elutes were dried in vacuo to yield 42.7, 25.4 and $10.1 \mathrm{~g}$ of $\mathrm{H}_{2} \mathrm{O}(\mathrm{F} 4-1), 40 \% \mathrm{EtOH}(\mathrm{F} 4-2)$ and $90 \% \mathrm{EtOH}$ (F4-3) fraction residues respectively. Fr. F4-1 is characterised by trace amount of phenolic compounds and was not investigated. Fr. F4-2 
was crystallised from $50 \%$ EtOH to give yellow precipitate $(11.4 \mathrm{~g})$ which was chromatographed on polyamide column $(3 \times 80 \mathrm{~cm})$, eluting with $\mathrm{H}_{2} \mathrm{O}-\mathrm{MeOH}(100: 0 \rightarrow 0: 100)$ to obtain 10 fractions (fr. F4-2/1-fr. F4-2/10). Frs. F4-2/2-F4-2/3 were combined and crystallised from $50 \%$ EtOH to give scolymoside (17; $92 \mathrm{mg})$ [35] and frs. F4-2/5-F4-2/6 after the same procedure give isorhoifolin (12; $34 \mathrm{mg}$ ) [32]. Fr. F4-3 was chromatographed on pHPLC (Summit HPLC-system with UV-V is detector (Dionex, Sunnyvale, CA, USA), column LiChrosorb RP-18 (4.6 × $250 \mathrm{~mm}, 5 \mu \mathrm{m}$, Merck), $\mathrm{T} 35{ }^{\circ} \mathrm{C}$, flow rate $1 \mathrm{~mL} / \mathrm{min}$; solvent, linear gradient of $5 \%-80 \%$ of $\mathrm{MeCN}$ in $\mathrm{H}_{2} \mathrm{O}$ for 90 min; detector at $330 \mathrm{~nm})$ to give rosmarinic acid $(3 ; 108 \mathrm{mg})$ and salvianolic acid B (4; $28 \mathrm{mg})$ [36].

\subsection{Microcolumn HPLC-UV}

The dried and powdered plant samples $(200 \mathrm{mg})$ were extracted with $60 \%$ ethanol $(5 \mathrm{~mL})$ in an ultrasonic bath for $40 \mathrm{~min}$ at $45^{\circ} \mathrm{C}$. The extracted solutions were filtered through a $0.22 \mu \mathrm{m}$ PTFE syringe filter before injection into the HPLC system for analysis. HPLC analysis was performed on a MiLiChrom A-02 microcolumn chromatograph (Econova, Novosibirsk, Russia) coupled with UV-detector, using a ProntoSIL-120-5-C18 AQ column $(2 \times 75 \mathrm{~mm}, \varnothing 5 \mu \mathrm{m}$; Metrohm AG, Herisau, Switzerland). Mobile phase A was $0.2 \mathrm{M} \mathrm{LiClO}_{4}$ in $0.006 \mathrm{M} \mathrm{HClO}_{4}$ and mobile phase $\mathrm{B}$ was acetonitrile. The injection volume was $1 \mu \mathrm{L}$, and elution at $150 \mu \mathrm{L} / \mathrm{min}$ with gradient programme $(0-7.5 \mathrm{~min}, 11 \%-18 \% \mathrm{~B} ; 7.5-13.5 \mathrm{~min}$, $18 \% \mathrm{~B} ; 13.5-15 \mathrm{~min}, 18 \%-20 \% \mathrm{~B}, 15-18 \mathrm{~min}, 20 \%-25 \% \mathrm{~B} ; 18-24 \mathrm{~min}, 25 \% \mathrm{~B} ; 24-30 \mathrm{~min}$, $25 \%-100 \%$ B). Detector wavelength was $270 \mathrm{~nm}$. Reference compounds with purity greater than $96 \%$ were used. This included 3-O-caffeoylquinic acid, caffeic acid, cichoric acid, rosmarinic acid, salvianolic acid B, apigenin, luteolin from Sigma-Aldrich; cosmosiin, isorhoifolin, cynaroside, luteolin-4'-O-glucoside, naringenin-7-O-glucoside, eriodictyol-7- $O$-glucoside from Extrasynthese (Lyon, France); luteolin-7-O-glucuronide from ChemFaces (Wuhan, China); scolymoside was isolated previously from Lophanthus chinensis Benth. herb [35].

\subsection{Preparation of the Extracts WSE and CSE}

The total herb of wild or cultivated samples of D. palmatum were air-dried and powdered in a mechanical grinder. The powdered total herb was weighted accurately $(100 \mathrm{~g})$, extracted twice with $60 \%$ ethanol $(1.5 \mathrm{~L})$ in an ultrasonic bath for $90 \mathrm{~min}$ at $45^{\circ} \mathrm{C}$. The extracted solutions were filtered through cellulose filter and evaporated in vacuo until dryness using rotary evaporator. The extracts yields are $35.63 \%$ (w/w; from wild sample, WSE) and 29.15\% (w/w; from cultivated sample, CSE).

\subsection{Antioxidant Activity Assays}

The total antioxidant capacity (TAC) was determined using the phosphomolybdic acid method [37]; the $\mathrm{DPPH}^{\circ}$ radical scavenging activity (DPPH-SA) was assessed as described by Asker and Shawky [38]; the $\mathrm{ABTS}^{\cdot+}$ radical scavenging activity $\left(\mathrm{ABTS}^{\circ+}-\mathrm{SA}\right)$ was measured using the method of Ding et al. [39]; the $\mathrm{Br}^{\circ}$ radical scavenging activity $\left(\mathrm{Br}^{\circ}-\mathrm{SA}\right)$ was determined using culometric method of Abdulin et al. [40] with electrogenerated bromine radicals; the determination of superoxide anion scavenging activity $\left(\mathrm{O}_{2}{ }^{--}\right.$-SA $)$was measured in phenazine methosulphate-nicotinamide adenine dinucleotide-nitroblue tetrazolium systems using the method of Ozen et al. [41]; $\beta$-carotene bleaching assay (CBA) was 
performed in $\beta$-carotene-oleic acid-DMSO- $\mathrm{H}_{2} \mathrm{O}_{2}$-system [42]; the NO inactivating activity (NO-IA) was measured using the sodium nitroprusside method [43]; the $\mathrm{H}_{2} \mathrm{O}_{2}$ inactivating activity $\left(\mathrm{H}_{2} \mathrm{O}_{2}\right.$-IA) was measured using the method of Badami and Channabasavaraj [44]; the chelating activity for $\mathrm{Fe}^{2+}$ ions (Fe-CA) was measured by the $o$-phenanthroline method [45]; the ferric reducing antioxidant power (FRAP) was determined using 2,4,6-tripyridyl-s-triazine (TPTZ) method [46]; the erythrocyte membrane stabilising activity (EM-SA) was determined using Fenton-induced hemolytic method [47].

\subsection{DPPH-HPLC-UV (ABTS-HPLC-UV) Procedure}

Briefly, D. palmatum extract solution in $60 \%$ ethanol $(500 \mu \mathrm{L}, 30 \mathrm{mg} / \mathrm{mL})$ were added to $\mathrm{DPPH}^{*}$ radical solution in methanol $(500 \mu \mathrm{L}, 20 \mathrm{mg} / \mathrm{mL})$ or ABTS $^{\circ+}$ radical solution in phosphate buffer $(\mathrm{pH} 7.4 ; 5 \mathrm{mg} / \mathrm{mL}$ ). The mixture was shaken for few seconds and left to stand in the dark for $30 \mathrm{~min}$ at room temperature. Then the sample was filtered through a $0.22 \mu \mathrm{m}$ membrane filter. The untreated sample was prepared by adding D. palmatum extract solution in $60 \%$ ethanol $(500 \mu \mathrm{L}, 30 \mathrm{mg} / \mathrm{mL})$ to methanol or phosphate buffer ( $\mathrm{pH} 7.4)(500 \mu \mathrm{L})$. HPLC analysis was performed on a MiLiChrom A-02 (Econova) microcolumn chromatograph coupled with a UV-detector, using a ProntoSIL-120-5-C18 AQ column $\left(2 \times 75 \mathrm{~mm}, \varnothing 5 \mu \mathrm{m}\right.$; Metrohm AG). Mobile phase A was $0.2 \mathrm{M} \mathrm{LiClO}_{4}$ in $0.006 \mathrm{M}$ $\mathrm{HClO}_{4}$ and mobile phase B was acetonitrile. The injection volume was $1 \mu \mathrm{L}$, and elution at $150 \mu \mathrm{L} / \mathrm{min}$ with gradient programme (0-15 min, 10\%-80\% B). Detector wavelength was $270 \mathrm{~nm}$.

\subsection{Statistical Analysis}

Statistical analyses were performed using a one-way analysis of variance (ANOVA), and the significance of the mean difference was determined by Duncan's multiple range test. Differences at $p<0.05$ were considered statistically significant. The results were presented as mean values $\pm \mathrm{SD}$ (standard deviations) of the three replicates.

\section{Conclusions}

Dracocephalum palmatum, a medicinal plant used by the North-Yakutian nomads, was investigated chemically for the first time. The presence of phenylpropanoids, coumarins, flavonoids and triterpenes in D. palmatum herb was shown. A comparative study of wild and cultivated samples demonstrated the lower level of the phenolic compounds in cultivated plants, possibly due to the fact that extreme environmental conditions increased the amount of these active compounds. However, both wild and cultivated plants could be used. The organ-specific distribution of phenolic compounds and the finding of eight new compounds specific to D. palmatum, which are not found in other species of Dracocephalum, suggest that this herb is one of the best sources of these phenolic compounds for humans. The high level of the antioxidant activity of the crude extract and isolated compounds was revealed using different in vitro methods. Obtained results confirmed the ethnopharmacological use of D. palmatum as a natural phytotherapeutic agent. 


\section{Acknowledgments}

The authors acknowledge the financial support provided by The Ministry of Education and Science of Russian Federation, Projects No 14.A 18.21.0217, 14.A18.21.1969, and the Presidium of Siberian Division of Russian Academy of Science under the "New Medical Technologies Centres" programme. The authors also thank Irina Khan for kindly providing the photo of D. palmatum.

\section{Conflicts of Interest}

The authors declare no conflict of interest.

\section{References}

1. Doron'kin, V.M.; Kovtonyuk, N.K.; Zuev, V.V. Flora of Siberia, 11; Nauka: Novosibirsk, Russia, 1997; pp. 170-185.

2. Yurinskii, T. Materials to the Flora of the Verkhoyansk Region of Yakutian Region. In The News of Yakutian Department of the Imperial Russian Geographic Association; Oblastnaya Tipographia: Yakutsk, Russia, 1915; Volume 1, pp. 26-58.

3. Dastmalchi, K.; Dorman, H.J.D.; Kosar, M.; Hiltunen, R. Chemical composition and in vitro antioxidant evaluation of a water soluble Moldavian balm (Dracocephalum moldavica L.) extract. Food Sci. Technol. 2007, 40, 239-248.

4. Singh, K.N. Traditional knowledge on ethnobotanical uses of plant biodiversity: A detailed study from the Indian western Himalaya. Biodivers. Res. Conserv. 2012, 28, 63-77.

5. Bdud Rtsi. A Canon of a Tibetan Medicine; Vostochnaya Literatura: Moscow, Russia, 2001; pp. 296-300.

6. Aseeva, T.A.; Dashiev, D.B.; Dashiev, A.D.; Nikolaev, S.M.; Surkova, N.A.; Chekhirova, G.V.; Yurina, T.A. Tibetan Medicine of Buryats; Publishing House of Russian Academy of Science: Novosibirsk, Russia, 2008; pp. 217-263.

7. Zeng, Q.; Jin, H.Z.; Qin, J.J.; Fu, J.J.; Hu X.J.; Lin, J.H.; Yan, L.; Chen, M.; Zhang, W.D. Chemical constituents of plants from the genus Dracocephalum. Chem. Biodivers. 2010, 7, 1911-1929.

8. Dai, L.; Zhao, C.; Jin, H.; Tang, J.; Shen, Y.; Li, H.; Peng, C.Y.; Zhang, W. A new ferulic acid ester and other constituents from Dracocephalum peregrinum. Arch. Pharm. Res. 2008, 31, $1325-1329$.

9. Guo, S.; Liu, Y. Studies on the flavonoids of Dracocephalum integrifolium Bge. Acta Bot. Sin. 1980, 22, 266-268.

10. Brown, J.E.; Rice-Evans, C.A. Luteolin-rich artichoke extract protects low density lipoprotein from oxidation in vitro. Free Rad. Res. 1998, 29, 247-255.

11. Halliwell, B.; Gutteridge, J.M.C. Free Radicals in Biology and Medicine; Oxford University Press Inc.: New York, NY, USA, 2007; p. 851.

12. Heim, K.E.; Tagliaferro, A.R.; Bobilya, D.J. Flavonoid antioxidants: Chemistry, metabolism and structure-activity relationships. J. Nutr. Biochem. 2002, 13, 572-584.

13. Rice-Evans, C.A.; Miller, N.J.; Paganga, G. Structure-antioxidant activity relationships of flavonoids and phenolic acids. Free Radic. Biol. Med. 1996, 20, 933-956. 
14. Tang, D.; Li, H.-J.; Chen, J.; Guo, C.-W.; Li, P. Rapid and simple method for screening of natural antioxidants from Chinese herb Flos Lonicerae Japonicae by DPPH-HPLC-DAD-TOF/MS. J. Sep. Sci. 2008, 31, 3519-3526.

15. Zhanga, Y.; Shia, S.; Wanga, Y.; Huang, K. Target-guided isolation and purification of antioxidants from Selaginella sinensis by offline coupling of DPPH-HPLC and HSCCC experiments. J. Chromatogr. B 2011, 879, 191-196.

16. Könczöl, Á.; Béni, Z.; Sipos, M.M.; Rill, A.; Háda, V.; Hohmann, J.; Máthé, I.; Balogh, G.T. Antioxidant activity-guided phytochemical investigation of Artemisia gmelinii Webb. ex Stechm.: Isolation and spectroscopic challenges of 3,5-O-dicaffeoyl(epi)quinic acid and its ethyl ester. J. Pharm. Biomed. Anal. 2012, 59, 83-89.

17. Zhang, Y.-P.; Shi, S.-Y.; Xiong, X.; Chen, X.-Q.; Peng, M.-J. Comparative evaluation of three methods based on high-performance liquid chromatography analysis combined with a 2,2'-diphenyl-1-picrylhydrazyl assay for the rapid screening of antioxidants from Pueraria lobata flowers. Anal. Bioanal. Chem. 2012, 402, 2965-2976.

18. Qiu, J.; Chen, L.; Zhu, Q.; Wang, D.; Wang, W.; Sun, X.; Liu, X.; Du, F. Screening natural antioxidants in peanut shell using DPPH-HPLC-DAD-TOF/MS methods. Food Chem. 2012, 135, 2366-2371.

19. Dai, X.; Huang, Q.; Zhou, B.; Gong, Z.; Liu, Z.; Shi, S. Preparative isolation and purification of seven main antioxidants from Eucommia ulmoides Oliv. (Du-zhong) leaves using HSCCC guided by DPPH-HPLC experiment. Food Chem. 2013, 139, 563-570.

20. Fuchs, J.; Milbradt, R. Skin anti-inflammatory activity of apigenin-7-glucoside in rats. Drug Res. 1993, 43, 370-372.

21. Zheng, Q.S.; Sun, X.L.; Xu, B.; Li, G.; Song, M. Mechanisms of apigenin-7-glucoside as a hepatoprotective agent. Biomed. Environ. Sci. 2005, 18, 65-70.

22. Rao, Y.K.; Lee, M.J.; Chen, K.; Lee, Y.C.; Wu, W.S.; Tzeng Y.M. Insulin-mimetic action of rhoifolin and cosmosiin isolated from Citrus grandis (L.) Osbeck leaves: Enhanced adiponectin secretion and insulin receptor phosphorylation in 3T3-L1 cells. Evid. Based Complement. Altern. Med. 2011, doi:10.1093/ecam/nep204.

23. Nakazaki, E.; Tsolmon, S.; Han, J.; Isoda, H. Proteomic study of granulocytic differentiation induced by apigenin 7-glucoside in human promyelocytic leukemia HL-60 cells. Eur. J. Nutr. 2013, 52, 25-35.

24. Park, J.C.; Park, J.G.; Kim, H.J.; Hur, J.M.; Lee, J.H.; Sung, N.J.; Chung, S.K.; Choi, J.W. Effects of extract from Angelica keiskei and its component, cynaroside, on the hepatic bromobenzene-metabolizing enzyme system in rats. Phytother. Res. 2002, 16, S24-S27.

25. Kim, T.-J.; Kim, J.-H.; Jin, Y.-R.; Yun, Y.-P. The inhibitory effect and mechanism of luteolin 7-glucoside on rat aortic vascular smooth muscle cell proliferation. Arch. Pharm. Res. 2006, 29, $67-72$.

26. Hua, J.M.; Hwang, N.K.; Hong, T.G.; Kim, Y.K.; Chung, H.K.; Yang, J.H.; Quan, Z.; Chang, H.W. Inhibitory activity of ethanol extracts of Ailanthus altissima and luteolin-7-glucoside on phospholipase A2 activity. Korean J. Pharmacogn. 2007, 38, 277-280. 
27. Azevedo, M.F.; Camsari, Ç.; Sá, C.M.; Lima, C.F.; Fernandes-Ferreira, M.; Pereira-Wilson, C. Ursolic acid and luteolin-7-glucoside improve lipid profiles and increase liver glycogen content through glycogen synthase kinase-3. Phytother. Res. 2010, 24, S220-S224.

28. Perez Gutierrez, R.M.; Anaya Sosa, I.; Hoyo Vadillo, C.; Victoria, T.C. Effect of flavonoids from Prosthechea michuacana on carbon tetrachloride induced acute hepatotoxicity in mice. Pharm. Biol. 2011, 49, 1121-1127.

29. Sun, X.; Sun, G.-B.; Wang, M.; Xiao, J.; Sun, X.-B. Protective effects of cynaroside against $\mathrm{H}_{2} \mathrm{O}_{2}$-induced apoptosis in H9c2 cardiomyoblasts. J. Cell. Biochem. 2011, 112, 2019-2029.

30. Kurihara, T.; Kikuchi, M.; Suzuki, S.; Toyoda, E. Studies on the constituents of leaves of Rhododendron degronianum Carr. Yakugaku Zasshi 1976, 96, 1407-1411.

31. Olennikov, D.N.; Tankhaeva, L.M. Biologically active substances from Cacalia hastata L. 5. Triperpenes and coumarines. Chem. Nat. Comp. 2005, 41, 600-601.

32. Malikov, V.M.; Yuldashev, M.P. Phenolic compounds of plants of the Scutellaria L. genus. Distribution, structure, and properties. Chem. Nat. Comp. 2002, 38, 358-406.

33. Lu, Y.; Foo, L. The polyphenol constituents of grape pomace. Food Chem. 1999, 65, 1-8.

34. Olennikov, D.N.; Stolbikova, A.V.; Tankhaeva, L.M.; Petrov, E.V. Phenylpropanoids and polysaccharides of Plantago depressa and P. media. Chem. Nat. Comp. 2001, 47, 165-169.

35. Olennikov, D.N.; Chirikova, N.K.; Tankhaeva, L.M. Chemical investigation of Lophanthus chinensis. Chem. Nat. Comp. 2010, 46, 301-302.

36. Kurkin, V.A. Phenylpropanoids from medicinal plants: Distribution, classification, structural analysis, and biological activity. Chem. Nat. Comp. 2003, 39, 123-153.

37. Preito, P.; Pineda, M.; Aguilar, M. Spectrophotometric quantitation of antioxidant capacity through the formation of a phosphomolybdenum complex: Specific application to the determination of vitamin E. Anal. Biochem. 1999, 269, 337-341.

38. Asker, M.M.S.; Shawky, B.T. Structural characterization and antioxidant activity of an extracellular polysaccharide isolated from Brevibacterium otitidis BTS 44. Food Chem. 2010, 123, 315-320.

39. Ding, H.; Chou, T.; Liang, C. Antioxidant and antimelanogenic properties of rosmarinic acid methyl ester from Origanum vulgare. Food Chem. 2010, 123, 254-262.

40. Abdullin, I.F.; Turova, E.N.; Budnikov, G.K. Coulometric determination of the antioxidant capacity of tea extracts using electrogenerated bromine. J. Anal. Chem. 2001, 56, 557-559.

41. Ozen, T.; Demirtas, I.; Aksit, H. Determination of antioxidant activities of various extracts and essential oil compositions of Thymus praecox subsp. skorpilii var. skorpilii. Food Chem. 2011, $124,58-64$.

42. Olennikov, D.N.; Tankhaeva, L.M.; Agafonova, S.V. Antioxidant components of Laetiporus sulphureus (Bull.: Fr.) Murr. fruit bodies. Appl. Biochem. Microbiol. 2011, 47, 419-425.

43. Kumar, S.; Kumar, D.; Jusha, M.; Saroha, K.; Singif, N.; Vashishta, B. Antioxidant and free radical scavenging potential of Citrullus colocynthis (L.) Schrad. methanolic fruit extract. Acta Pharm. 2008, 58, 215-220.

44. Badami, S.; Channabasavaraj, K.P. In vitro antioxidant activity of thirteen medicinal plants of India's Western Ghats. Pharm. Biol. 2007, 45, 392-396.

45. Olennikov, D.N.; Agafonova, S.V.; Stolbikova, A.V.; Rokhin, A.V. Melanin of Laetiporus sulphureus (Bull.: Fr.) Murr sterile form. Appl. Biochem. Microbiol. 2011, 47, 298-303. 
46. Benzie, I.F.; Strain, J.J. The ferric reducing ability of plasma (FRAP) as a measure of “Antioxidant Power": The FRAP assay. Anal. Biochem. 1996, 239, 70-76.

47. Olennikov, D.N.; Tankhaeva, L.M. Lamiaceae carbohydrates. I. Pectinic substances and hemicelluloses from Mentha piperita. Chem. Nat. Comp. 2007, 43, 501-507.

Sample Availability: Samples of the compounds 1-24 and D. palmatum extracts are available from the authors.

(C) 2013 by the authors; licensee MDPI, Basel, Switzerland. This article is an open access article distributed under the terms and conditions of the Creative Commons Attribution license (http://creativecommons.org/licenses/by/3.0/). 